\title{
Effects of environmental stress on ascidian populations in Algeciras Bay (southern Spain). Possible marine bioindicators?
}

\author{
S. A. Naranjo*, J. L. Carballo, J. C. García-Gómez \\ Laboratorio de Biología Marina, Dpto. de Fisiología y Biología Animal, Facultad de Biología, Apdo 1095, E-41080 Sevilla, Spain
}

\begin{abstract}
The distribution and abundance of littoral ascidians were analyzed with respect to their possible relationships with environmental stress. As part of a multidisciplinary research project on the benthic communities in Algeciras Bay, southern Spain, a suite of environmental variables was measured (hydrodynamism, silting, suspended solids and organic matter). After displaying the similarities of fauna through clustering and ordination of sampling sites, the relationships between community differences and changes in the abiotic component were established based on the BIO-ENV procedure and Canonical Correspondence Analysis. Hydrodynamism and the percentage of organic matter in the silt is the variable combination that best explains (Spearman correlation of 0.82 ) the biotic structure. While all ascidians show a certain tolerance to diverse environmental factors, some species such as Ciona intestinalis, Diplosoma spongiforme, Phallusia mammillata, Microcosmus squamiger. Styela plicata and Synoicum argus could be considered as indicators of areas which have been subject to intense stress (substrate transformation, water stagnation and sedimentation excess) over long periods of time, whereas others such as Aplidium conicum, Aplidium punctum. Clavelina dellavallei, Halocynthia papillosa and Stolonica socialis, which live only in natural and non-perturbed rock areas, could be categorized as species very sensitive to stress, as well as indicators of good conditions.
\end{abstract}

KEY WORDS: Ascidian communities - Environmental stress - Multivariate community measurements Bioindicators

\section{INTRODUCTION}

There is now widespread recognition that chemical monitoring of pollution alone is not enough, and that pollution is essentially a biological phenomenon because of its impact on living organisms (Wright et al. 1994). The analysis of changes in benthic community structure has now become one of the mainstays in detecting and monitoring the biological effects of marine pollution (Warwick \& Clarke 1993). Nevertheless, knowledge of the distribution patterns of benthic organisms along natural environmental gradients (e.g. from turbulent to calm conditions) is necessary before a possible anthropogenic disturbance can be proved.

Algeciras Bay features important industrial developments (with chemical industries, refineries, thermal

·E-mail: naranjo@cica.es power plants, ironworks and paper mills) as well as intense harbour activity. All of this results in a highly transformed coastline (mainly in the central zone) where shipyards, piers and breakwaters, among other port constructions, affect the normal water flow. Some areas that are better conserved and have natural rocks exist in the outer zone. Recent studies show the amount of direct waste in this area to be close to $2800 \mathrm{~m}^{3} \mathrm{~h}^{-1}$, with much more urban sewage than industrial waste-waters (Wait et al. 1990). Consequently, Algeciras Bay can be considered to be a patchwork of small areas under different levels of stress due to the influence of environmental and anthropogenic factors. Thus, a multitude of small environments can be identified and, correspondingly, a similar level of heterogeneity can be expected in the structure of the benthic communities within these environments.

Algeciras Bay is considered to be an especially suitable area for biomonitoring studies (Naranjo \& García- 
Gómez 1993, Carballo et al. 1994, Conradi \& Cervera 1995, Carballo et al. 1996). In this sense, a multidisciplinary research program was conducted from 1991 to 1995 in order to gain knowledge of the macrobenthic fauna and its relation to major environmental variables in this area. Among all sessile organisms studied, the ascidians are a particularly interesting group in this respect, since they display both of the main ecological strategies-solitary and colonial-and a variety of morphological types which are of adaptive significance (Jackson 1977a, 1979) and which correlate with distinct abilities for colonizing new surfaces. Accordingly, it is a good diagnostic group whose distribution may reflect some of the prevailing structuring factors affecting benthic assemblages (Turon 1990)

Ascidians are found on all submerged hard surfaces, including concrete, iron, rope and plastics. Some species are most abundant in highly transformed and nolluted environments such as ports, harbors and industrial areas, where the excess of particulate organic matter and the proliferation of bacteria are a source of food for filter-feeding invertebrates, particularly ascidians (Monniot et al. 1991).

Ascidians can also take up various metals from the water (vanadium is one of the most common) and some toxic substances (heavy metals and hydrocarbons). Therefore, ascidians contribute to the cleaning and purification of waste-waters. For this reason, numerous studies have outlined the importance of this group as pollution bioindicators (Papadopoulou et al. 1972, Papadopoulou \& Kanias 1977. Monniot 1978, Bell et al. 1982). In spite of this, little is known about the influence of local environmental factors (such as water movement, suspended solids or silting) on the presence or absence of the species in a given habitat. In this sense, we have studied the composition and abundance of the ascidian communities in Algeciras Bay, as well as their level of adaptation to abiotic components.

\section{MATERIAL AND METHODS}

Ascidians were sampled at 11 coastal stations distributed around Algeciras Bay, at depths from 3 to $15 \mathrm{~m}$. Their locations are shown in Fig 1. Due to the heterogeneity of the hard-bottom habitats (natural. rock formations, port constructions, shipyards and other artificial substrates), the stations were selected on the basis of environmental variability.

Inventories of species per station were taken of the specimens collected by SCUBA-divers a long continuous transects (approximately $50 \mathrm{~m}$ long). These inventories were completed by visual and photographic sampling along the same transects, with a similar immersion time at

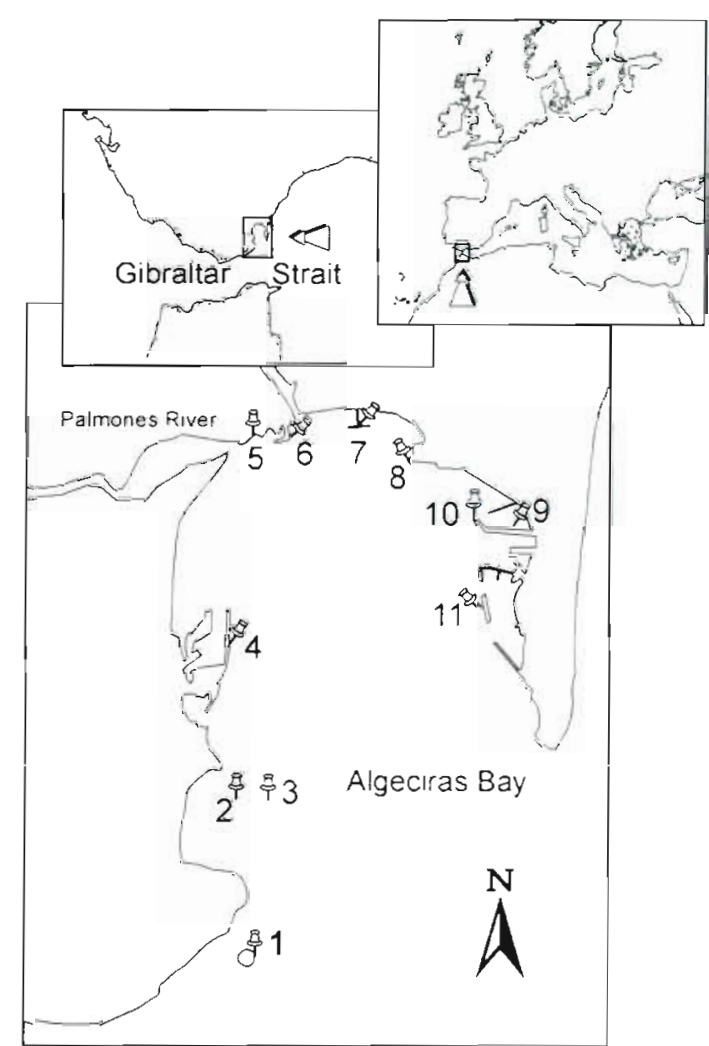

Fig. 1 Location of the sampling stations in Algeciras Bay, southern Spain

all stations (there were no replicates on any occasion). All ascidians sighted at a distance of $1 \mathrm{~m}$ on either side of the transects were collected and/or photographed. Surveys were taken from September 1992 to November 1993

Table 1 shows the species abundance in terms of semi-quantitative abundance codes. Coding can be useful when different sampling methods are utilized, and in this study it permitted more objective comparisons of the faunistic composition at different stations (Carballo et al. 1996). Furthermore, this procedure is presumed to have an effect similar to standardization by columns, which minimizes data variability arising from sampling heterogeneity (Maldonado \& Uriz 1995).

The establishment of environmental variability among stations was based on the analysis of 5 abiotic variables that could be related to environmental stress. These were hydrodynamism, silting, suspended solids, suspended organic matter and organic matter in the silt (SOM) gathered in collecting bottles. The methods used to estimate these parameters are detailed in Carballo et al. (1996); measurement was made as in Gambi et al. (1989) for hydrodynamism, Moore (1972) for silling and Strickland \& Parsons (1960) for the other three. As a preparatory step to the statistical analysis, these abiotic variables were log-transformed. 
Comparisons among sampling stations (on the basis of species abundance) were conducted according to the strategy outlined by Field et al. (1982) for the analysis of data on community structure: (a) The biotic relationship between any 2 samples (sampling stations in our case) was distilled into a coefficient measuring similarity (or dissimilarity) in species composition. The Bray-Curtis index (Bray \& Curtis 1957), which is not a function of joint absence, was chosen for this purpose. It is recognized as an efficient measure for the evaluation of affinities on semi-quantitative data from large faunistic assemblages (Gamito \& Raffaelli 1992). (b) Stations were classified into groups (using the triangular matrix of similarity obtained between every pair of stations) either by hierarchical agglomerative clustering, with group-average linking (e.g. Sneath \& Sokal 1973), or by mapping the station interrelationships into ordination using non-metric multidimensional scaling (MDS) (Kruskal \& Wish 1978). (c) Relationships between species were analyzed by transposing the data matrix and repeating the classification and ordination methods on the new similarity matrix between every pair of species. Species which were indicative of the dissimilarity between groups of stations were determined as in Clarke (1993), using the SIMPER computer program.

In order to link the multivariate community structure (reflected in the faunistic heterogeneity of the different sampling stations) to environmental variables (which also change with each station), we used 2 different, but complementary, statistical techniques:

(1) BIO-ENV procedure (Clarke \& Ainsworth 1993). In summary, this consists of a separate comparison of the among-station similarity matrix for the biota with equivalent triangular matrices for all combinations of abiotic variables, and the consequent choice of the subset of environmental variables which provides a good match between the 2 configurations. A match was measured by the Spearman rank correlation coefficient $\left(\rho_{\mathrm{s}}\right)$, which was computed for the dissimilarity matrices of the biotic and abiotic data. Although no specific plot is provided showing the result, a diagram displaying the biotic MDS (based on the Bray-Curtis dissimilarity index) in conjunction with the abiotic MDSs (computed from Euclidean distances) for the subset of environmental variables selected by the BIO-ENV procedure as optimal would be appropiate, especially when high values of $\rho_{s}$ are obtained (e.g. $\rho_{\mathrm{s}} \gg 0.8$ ) (Clarke \& Ainsworth 1993).

(2) Canonical Correspondence Analysis (CCA). This is a direct gradient technique, and represents a special case of multivariate regression (Palmer 1993). In the resulting ordination diagram, environmental variables can be represented by arrows along with the species and/or station scores. Details of how to interpret CCA diagrams are given in ter Braak (1986) and Palmer (1993).
The software used was: PRIMER version 3.1 from Plymouth Marine Laboratory, UK, for cluster, MDS, SIMPER and BIO-ENV analysis; STATGRAPHICS 6.0 for regression analysis; and CANOCO 3.12 for Correspondence Analysis, CCA and Montecarlo permutation tests

\section{RESULTS}

\section{Station groupings based on species composition}

Table 1 indicates large variability in the nature, type and availability of hard substrates characterizing the sampling stations. A preliminary study of the local distribution of the most common ascidians indicated 3 basic groups: (a) species exclusively distributed in the outer zone of the bay which settle mainly on natural rock substrates; (b) species more abundant in the inner zone of the bay which settle mainly on artificial substrates; (c) species found throughout the bay.

Analysis of the dendrogram in Fig. 2 shows the differences among the stations as stated above. This classification technique separates the stations into 3 major groups (A, B, C) which are related, in part, to the nature of the substrate. In group $A$, the stations are characterized by the presence of extensive natural rock formations (in the extremes of the bay). Groups $B$ and $C$ include the rest of the stations (in the inner parts of the bay), where artificial substrates are dominant (walls and columns in ports, breakwaters, shipyards, etc.).

The average dissimilarity between groups $\mathrm{A}$ and $\mathrm{B}$ is $59.74 \%$. As is shown in Table 2, 17 of the 38 species explain the dissimilarity of $70 \%$ between groups $\mathrm{A}$ and B. Pseudodistoma obscurum, Polycitor adriaticum,

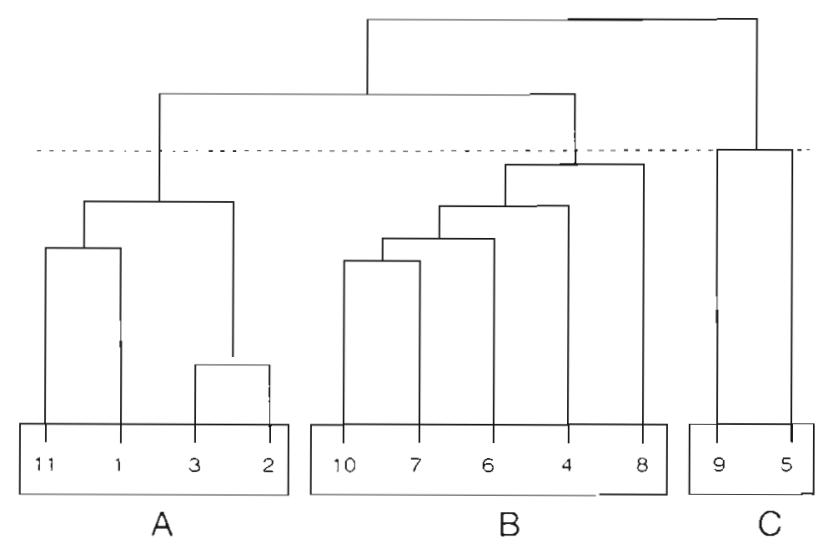

Fig. 2. Dendrogram of stations using group-average clustering from Bray-Curtis similarity on species abundances. The 3 groups of stations (A to C) separated at a $50 \%$ similarity threshold (dotted line) are indicated 
Table 1. Ascidian species abundance in Algeciras Bay and substrate characteristics at sampling stations. Semıquantitative abundance codes: 0 = species absent; 1 = rare ( 1 or 2 specimens recorded); $2=$ frequent (from 3 to 10 specimens per immersion); 3 = very common (an average of more than 10 specimens per immersion). Substrate orientation: H $=$ horizontal surfaces; $V=$ vertical surfaces; $\mathrm{O}=$ overhangs; $\mathrm{U}=$ under boulders; $\mathrm{C} c=$ crevices and cavities; $E=$ epibion. Natural rock types: $\mathrm{a}=\mathrm{large}$ submerged boulders; $\mathrm{b}=$ small stones on sandy bottoms; $\mathrm{c}=$ rock slabs; $\mathrm{d}=$ biodetritic bottoms; e $=$ Caulerpa prolifera weeds. Artificial substrate types: $a=$ piling of concrete blocks in breakwaters; $b=$ vertical surfaces in port walls; $c=$ piers in shipyards; $\mathrm{d}=$ others artificial structures scattered on bottom

\begin{tabular}{|c|c|c|c|c|c|c|c|c|c|c|c|c|}
\hline $\begin{array}{r}\text { Depth }(\mathrm{m}): \\
\text { Artificial substrate: } \\
\text { Natural rock: }\end{array}$ & $\begin{array}{c}3 \text { to } 7 \\
- \\
a, b\end{array}$ & $\begin{array}{c}8 \text { to } 15 \\
- \\
a, b\end{array}$ & $\begin{array}{c}3 \text { to } 5 \\
- \\
a, b, c\end{array}$ & $\begin{array}{c}3 \text { to } 10 \\
b, c \\
c\end{array}$ & $\begin{array}{c}0 \text { to } 4 \\
\text { a,c } \\
c\end{array}$ & $\begin{array}{l}2 \text { to } 6 \\
a, c, d \\
c, d\end{array}$ & $\begin{array}{c}10 \text { to } 18 \\
b, c, d \\
c, d\end{array}$ & $\begin{array}{c}3 \text { to } 9 \\
a_{1} d \\
c\end{array}$ & $\begin{array}{c}2 \text { to } 5 \\
d \\
c, e\end{array}$ & $\begin{array}{l}1 \text { to } 6 \\
a, c, d \\
c, d\end{array}$ & $\begin{array}{l}4 \text { to } 10 \\
b, d \\
a, c\end{array}$ & $\begin{array}{l}\text { Substrate } \\
\text { orlentation }\end{array}$ \\
\hline Species & $\operatorname{Stn} 1$ & $\operatorname{Stn} 2$ & $\operatorname{Stn} 3$ & $\operatorname{Stn} 4$ & Stn 5 & $\operatorname{Stn} 6$ & $\operatorname{Stn} 7$ & $\operatorname{Stn} 8$ & $\operatorname{Stn} 9$ & $\operatorname{Stn} 10$ & $\operatorname{Sin} 11$ & \\
\hline Apledium conicum & 2 & 2 & 3 & 3 & 0 & 0 & 0 & 2 & 0 & 2 & 3 & V.O \\
\hline Aplidium elegans & 1 & 3 & 2 & 2 & 0 & 0 & 3 & 3 & 0 & 2 & 0 & $H, V, O, E$ \\
\hline Aplidium pallidum & 0 & 2 & 2 & 0 & 0 & 0 & 0 & 0 & 0 & 0 & 0 & V.E \\
\hline Aplidium punctum & 0 & 3 & 3 & 1 & 0 & 0 & 0 & 0 & 0 & 0 & 0 & $\mathrm{~V}, \mathrm{O}$ \\
\hline Ascidia mentula & 0 & 0 & 1 & 0 & 0 & 1 & 2 & 0 & 0 & 1 & 0 & $\mathrm{~V}, \mathrm{O}, \mathrm{U}, \mathrm{C}$ \\
\hline Ascidiella aspersa & 0 & 0 & 0 & 0 & 0 & 0 & 0 & 0 & 3 & 0 & 0 & $\mathrm{E}$ \\
\hline Ascidiella scabra & 0 & 0 & 0 & 0 & 0 & 0 & 1 & 1 & 0 & 1 & 0 & U, C \\
\hline Botryllus leachi & 1 & 2 & 3 & 3 & 0 & 3 & 3 & 2 & 1 & 2 & 2 & $\mathrm{~V}, \mathrm{O}, \mathrm{U}, \mathrm{E}$ \\
\hline Botryllus schlosseri & $\hat{1}$ & 1 & 1 & 2 & 0 & 1 & 1 & 1 & 1 & 1 & 1 & $V, O, U, C$ \\
\hline Clond edwardsi & $\hat{i}$ & 1 & 1 & 1 & 0 & 1 & 1 & 0 & $\hat{0}$ & 0 & 0 & $U, C$ \\
\hline Ciona intestmalis & 0 & 0 & 0 & 0 & 1 & 0 & 1 & 0 & 0 & 1 & 0 & U,C \\
\hline Clavelina dellavallei & 0 & 3 & 3 & 0 & 0 & 0 & 0 & 0 & 0 & 0 & 0 & $\mathrm{~V}, \mathrm{O}, \mathrm{E}$ \\
\hline Clavelina lepadiformis & 1 & 1 & 1 & 2 & 1 & 3 & 3 & 1 & 0 & 2 & 1 & $\mathrm{~V}, \mathrm{O}, \mathrm{E}$ \\
\hline Clavelina nana & $\hat{1}$ & 1 & 1 & 2 & 0 & 1 & 3 & 0 & 0 & 1 & 1 & $\mathrm{O}, \mathrm{C}$ \\
\hline Didemnum coriaceum & 0 & 0 & 1 & 1 & 0 & 0 & 1 & 1 & 0 & 0 & 0 & O,U,C \\
\hline Didemnum maculosum & 1 & 2 & 2 & 2 & 0 & 0 & 2 & 2 & 0 & 0 & 1 & $\mathrm{H}, \mathrm{V}, \mathrm{O}, \mathrm{U}, \mathrm{E}$ \\
\hline Diplosoma listerianum & 1 & 1 & 1 & 2 & 0 & 0 & 1 & 1 & 0 & 1 & 0 & $V, O, U, C, E$ \\
\hline Diplosoma spongiforme & 1 & 1 & 1 & 3 & 0 & 0 & 3 & 1 & 0 & 2 & 1 & $V, O, U, C, E$ \\
\hline Distomus variolosus & 1 & 1 & 1 & 1 & 0 & 2 & 2 & 3 & 0 & 0 & 1 & $\mathrm{H}, \mathrm{E}$ \\
\hline Halocynthia papillosa & 1 & 0 & 1 & 1 & 0 & 0 & 0 & 0 & 0 & 0 & 0 & $\mathrm{O}, \mathrm{C}$ \\
\hline Microcosmus squamiger & 0 & 0 & 1 & 2 & 3 & 3 & 3 & 2 & 1 & 3 & 0 & $H_{1} \mathrm{~V}$ \\
\hline Molgula bleizel & 0 & 0 & 0 & 0 & 0 & 0 & 0 & 0 & 3 & 0 & 0 & $E$ \\
\hline Molgula occidentalis & 0 & 0 & 0 & 1 & 0 & 0 & 0 & 1 & 0 & 0 & 0 & $H_{1} \mathrm{~V}$ \\
\hline Phallusia fumigata & 0 & 2 & 2 & 1 & 0 & 0 & 0 & 0 & 0 & 1 & 0 & $\mathrm{O}, \mathrm{U}, \mathrm{C}$ \\
\hline Phallusia ingeria & 0 & 0 & 1 & 0 & 0 & 0 & 1 & 1 & 1 & 0 & 0 & $H, V$, \\
\hline Phallusia mammillata & 0 & 0 & 0 & 2 & 2 & 2 & 2 & 0 & 2 & 1 & 2 & $\mathrm{H}, \mathrm{V}$ \\
\hline Polycitor adriaticum & 3 & 3 & 3 & 3 & 0 & 0 & 0 & 0 & 0 & 0 & 3 & $\mathrm{~V}, \mathrm{O}$ \\
\hline Polycitor cristalinum & 0 & 3 & 2 & 0 & 0 & 0 & 0 & 0 & 0 & 0 & 2 & $\mathrm{H}, \mathrm{V}, \mathrm{O}$ \\
\hline Polysyncraton lacazei & 1 & 1 & 1 & 2 & 0 & 0 & 0 & 0 & 0 & 0 & 0 & O,U,C \\
\hline Pseudodistoma obscurum & 2 & 3 & 3 & 0 & 0 & 0 & 0 & 0 & 0 & 0 & 2 & $\mathrm{H}, \mathrm{V}, \mathrm{O}$ \\
\hline Pyura microcosmus & 0 & 1 & 0 & 0 & 0 & 0 & 2 & 1 & 0 & 0 & 0 & O,U.C \\
\hline Rhopalaea neapolitana & 0 & 1 & 1 & 0 & 0 & 0 & 0 & 0 & 0 & 0 & 1 & $\mathrm{U}, \mathrm{C}$ \\
\hline Stolonica socialis & 0 & 1 & 2 & 0 & 0 & 0 & 0 & 0 & 0 & 0 & 0 & $\mathrm{~V} O$ \\
\hline Styela canopus & 0 & 1 & 1 & 0 & 0 & 0 & 1 & 0 & 0 & 0 & 0 & $\mathrm{H}, \mathrm{V}$ \\
\hline Styela plicata & 0 & 1 & 0 & 1 & 2 & 0 & 2 & 0 & 1 & 1 & 0 & $H_{1} \mathrm{~V}$ \\
\hline Synoicum argus & 0 & 2 & 0 & 3 & 3 & 3 & 3 & 2 & 3 & 3 & 1 & $\mathrm{H}, \mathrm{V}$ \\
\hline Synoicum blochmanni & 1 & 1 & 1 & 0 & 0 & 0 & 0 & 2 & 0 & 0 & 2 & $\mathrm{O}, \mathrm{C}$ \\
\hline Trididemnum cereum & 0 & 2 & 3 & 0 & 0 & 0 & 0 & 1 & 0 & 0 & 0 & H, V.E \\
\hline
\end{tabular}

Microcosmus squamiger and Synoicum argus can be considered as good discriminators because they contribute the highest values to the average dissimilarity $(\bar{\delta})$ and because they have reasonably high values of the $\bar{\delta}_{t} / \mathrm{SD}\left(\bar{\delta}_{1}\right)$ ratio (Clarke 1993). The stations which make up group $C$ (5 and 9) show the lowest levels of specific richness in the bay and have a faunistical composition typical of harbour areas (Microcosmus squamiger, Styela plicata, Synoicum argus, etc.); thus, they are more closely related to the stations in group $B$ ( $40 \%$ similarity).
MDS ordination was performed using the similarities between species. In the resulting 2-dimensional configuration a definite species aggregation can be observed, but a direct intrepretation could be inaccurate: Molgula bleizei and Ascidiella aspersa are abundant but exclusive to $\operatorname{Stn} 9$, so their similarity with the other species is very low. The removal of these outlier species is recommended (Gauch 1982, Clarke \& Green 1988) in order to obtain a more reliable picture of the remaining species. Although stress tends to decrease as dimensionality is increased (Field et al. 1982), when MDS was performed 
in 3 dimensions (Fig. 3), the species' relationships became more evident. In Fig. 3 it is possible to identify several groups of species based on the major trends of distribution in the bay: species mainly distributed at the outer part of bay (Stns 1 to 3) which live on natural rock are on the right side of the diagram (Aplidium pallidum, Stolonica socialis, Clavelina dellavallei, Trididemnum cereum, Pseudodistoma cristallinum, Aplidium punctum, Phallusia fumigata, Rhopalaea neapolitana, Synoicum blochmanni, Pseudodistoma obscurum). Species which are considered to have a medium level of tolerance in relation to the substrate (Polycitor adriaticum, Aplidium conicum, Ciona edwardsi, Aplidium elegans, Didemnum maculosum, Clavelina nana, Botryllus leachi, etc.) are grouped in the middle; they are more abundant over natural rock, but they can also colonize artificial substrates. These species are distributed throughout practically all of the bay, except for the most internal areas (piers and shipyards). Finally, species grouped on the left (Ciona intestinalis, Microcosmus squamiger, Synoicum argus, Styela plicata, Phallusia mammillata and Clavelina lepadiformis) are typical species of harbour areas and colonize every type of artificial surface.

\section{Relationship between species and environmental variables}

\section{Abiotic characteristics of the stations}

Because of the many coastal transformations in Algeciras Bay (due mainly to industrial development), the
Table 2. Average abundance $(\bar{Y})$ of important ascidian species in groups A (1 to 3,11$)$ and $B(4,6$ to 8,10$)$ at Algeciras Bay stations. Species are listed in orer of their contribution $\left(\bar{\delta}_{1}\right)$ to average dissimilarity $(\bar{\delta})(=59.74)$ between the 2 groups (only partly given). Species names given in full in Table 1

\begin{tabular}{llllllr} 
Species & $\bar{y}_{B}$ & $\bar{y}_{A}$ & $\bar{\delta}$, & $\operatorname{SD}\left(\delta_{j}\right)$ & $\bar{\delta}_{i} / S D\left(\delta_{l}\right)$ & $\sum \bar{\delta}_{l}(\%)$ \\
\hline S. argus & 2.8 & 0.25 & 4.15 & 1.38 & 3.01 & 6.95 \\
P. adriaticum & 0.6 & 3.0 & 4.13 & 2.41 & 1.71 & 13.86 \\
M. squamiger & 2.6 & 0.25 & 4.02 & 1.84 & 2.18 & 20.58 \\
P. obscurum & 0.0 & 2.5 & 3.97 & 0.64 & 6.25 & 27.24 \\
P. cristalinus & 0.0 & 1.75 & 2.63 & 1.73 & 1.52 & 31.63 \\
A. conicum & 1.2 & 2.5 & 2.51 & 1.90 & 1.32 & 35.84 \\
A. elegans & 2.0 & 1.25 & 2.14 & 1.73 & 1.23 & 39.41 \\
S. blochmanni & 0.4 & 1.5 & 2.13 & 1.20 & 1.78 & 42.98 \\
A. punctum & 0.2 & 1.5 & 2.06 & 1.95 & 1.06 & 46.44 \\
C. dellavallei & 0.0 & 1.5 & 2.02 & 2.11 & 0.96 & 49.82 \\
C. lepadiformis & 2.2 & 1.0 & 1.99 & 1.46 & 1.37 & 53.15 \\
P. mammillata & 1.4 & 0.5 & 1.92 & 1.52 & 1.26 & 56.36 \\
D. spongiforme & 1.8 & 1.0 & 1.86 & 1.10 & 1.70 & 59.48 \\
T. cereum & 0.2 & 1.25 & 1.73 & 1.61 & 1.08 & 62.38 \\
D. variolosus & 1.6 & 1.0 & 1.71 & 1.18 & 1.45 & 65.24 \\
D. maculosum & 1.2 & 1.5 & 1.58 & 1.17 & 1.35 & 67.90 \\
D. listerianum & 1.4 & 0.75 & 1.55 & 1.11 & 1.40 & 70.49 \\
\hline
\end{tabular}

influence of hydrological factors along its margins is uneven. The 5 environmental variables recorded showed a notable variability at both spatial and temporal levels (the latter is not taken into account in this work). Fig. 4 (b to g) shows a multiple box and whisker plot for each variable analyzed. In spite of some sampling stations being placed differently, the relationships among stations were similar to the ones in Carballo et al. (1996).

Due to the proximity of the Straits of Gibraltar, the hydrodynamic conditions depend on major coastal currents and, in consequence, on tidal flows and prevailing winds. Extreme values of hydrodynamism were registered at outer (and more exposed) stations (1 to 3 and 11). The high hydrodynamism recorded at Stn 8 can be explained by the influence of 2 littoral currents which appear during low-tide periods (Camiñas 1987).
Fig. 3. Three-dimensional MDS configuration of species similanty matrix (stress $=0.09$ ) Values of Ascidiella aspersa and Molgula bleizei were removed previous to analyses. Species names are abbreviated from Table 1

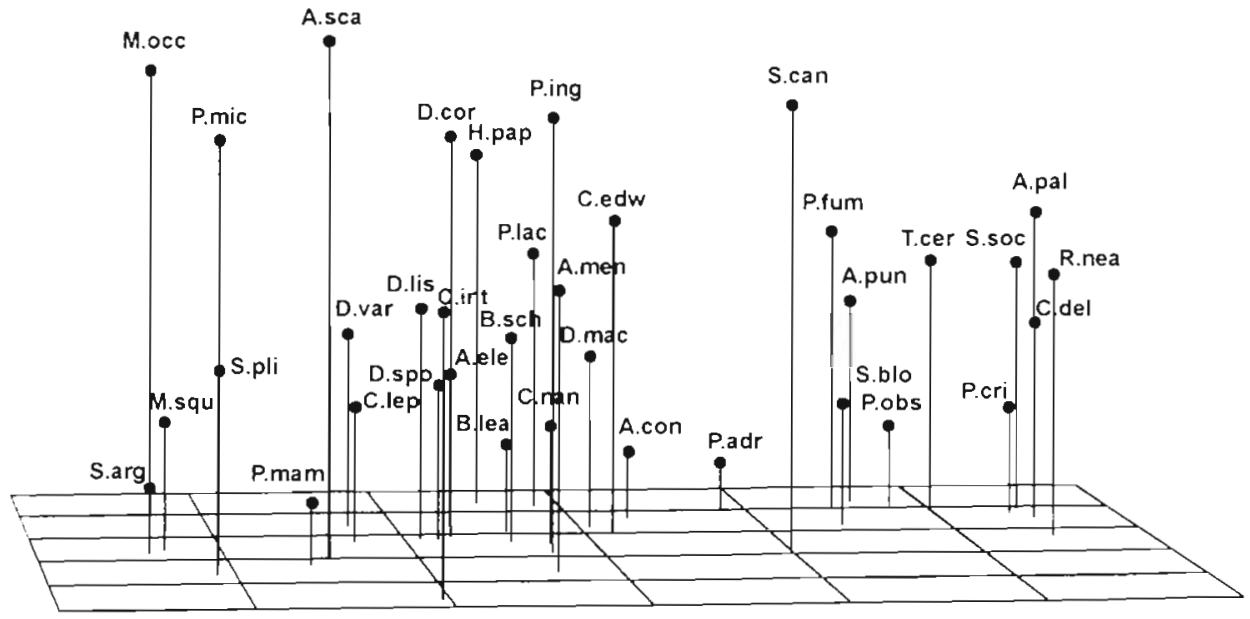




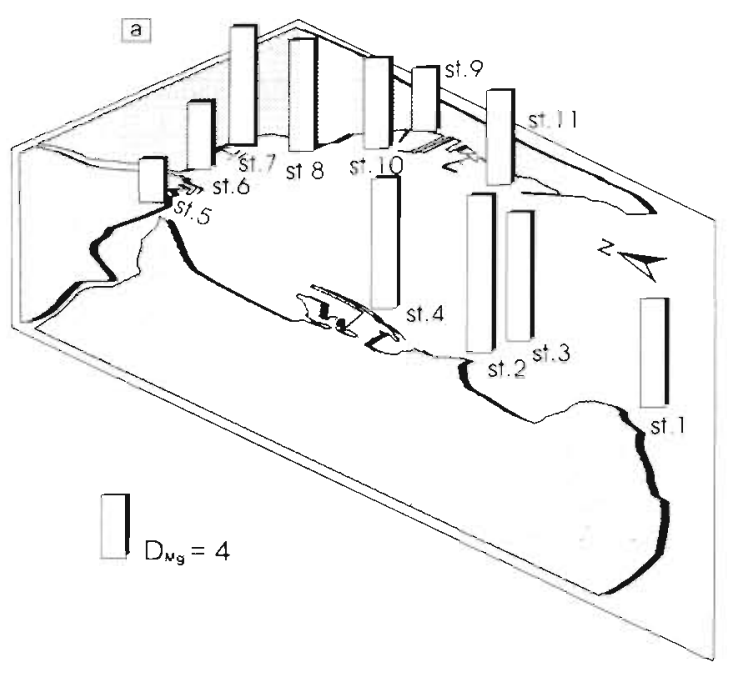

Fig. 4. (a) Specific richness $\left(D_{\mathrm{Nig}}\right)$ of ascidians at the sampling stations; (b to g) multiple box and whisker plot for each abiotic factor registered at the 11 sampling stations. (d) as (c) but without Stn 5
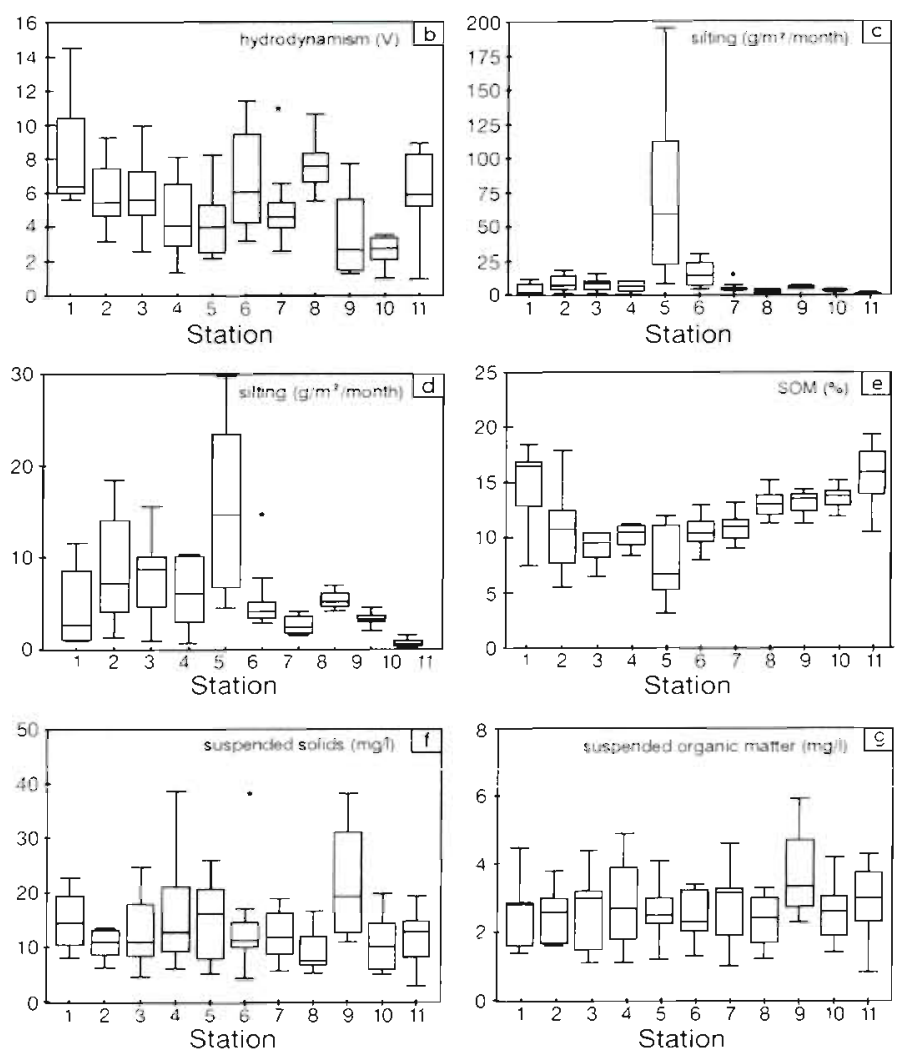

In general, hydrodynamism is inversely related to silting, but at Stn 5 these parameters seem occasionally parallel (e.g. during the rainy season). The unusual conditions of this area are due to the influence of the Palmones River (sedimentation is increased by the river's flow). Thus, both the extreme and the highest average annual values for silting (195.6 and $74.04 \mathrm{~g}$ $\mathrm{m}^{-2} \mathrm{mo}^{-1}$, respectively) and for SOM (13.2 and $7 \mathrm{~g} \mathrm{~m}^{-2}$ $\mathrm{mo}^{-1}$, respectively) were registered here. On the other hand, suspended solids and suspended organic matter reached the highest values at Stn 9, where water renewal is limited by a partially enclosed harbour zone.

Hydrodynamism seems to influence the other factors. Several environmental relationships can be established anong the set of variables measured (and logtransformed) by using correlation analysis. Whereas hydrodynamism and suspended solids show a negative correlation ( $r=-0.72 ; p=0.018$ ), a positive linear relationship exists between silting and suspended solids $(r=0.54 ; p<0.1)$, as well as between both variables and their organic matter contents (absolute values only, see Fig. 5).

Univariate and multivariate community measures

After the variation levels of major hydrological factors were recorded, different statistical methods were car- ried out in order to establish a relationship between abiotic heterogeneity and faunal distribution (from ascidian species abundance) throughout the survey area

As a first approximation, the biotic information relative to each sampling station was summarized by simple univariate measures such as the number of species found $(S)$ or the specific richness. For this purpose, specific richness has been established from the Margalef index: $D_{\mathrm{Mg}}=S-1 / \ln (N)$, where $N$ is the total number of specimens collected (e.g. Bakus 1990). Although $S$ and $D_{\mathrm{Mg}}$ are usually correlated (for this case: $r=0.67 ; p<0.05)$, specific richness gives a quantitative measure of diversity avoiding some problems inherent to other indexes such as Shannon's or Simpson's (Maguran 1989).

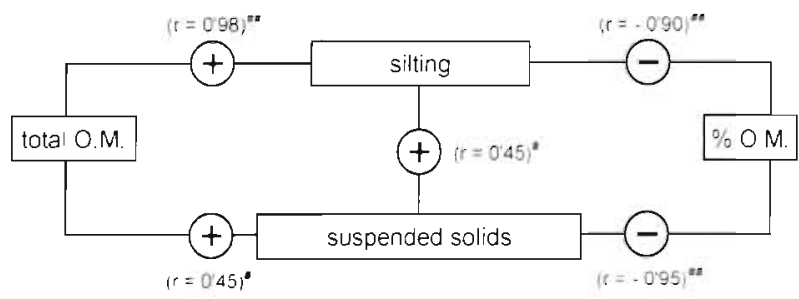

Fig. 5. Linear correlations between the organic matter (O.M.) content (total and percentage) with silting and suspended solids. +: positive, and -: negative correlations. "p $<0.1$; $=0.001$ 
Fig. 4a shows the specific richness throughout the bay. The low values for this parameter $\left(D_{\mathrm{Mg}}<3.1\right)$ obtained at Stns 5, 6 and 9 are remarkable, as well as the highest specific richness $\left(D_{M g}>7\right)$ at $\operatorname{Stn} 2$. This biotic information provided no significant relationship with the set of environmental variables considered here; however, a definite positive relationship between specific richness and hydrodynamism and an inverse one with respect to suspended solids is suggested $(r=0.53$ and $r=-0.51$, respectively; $p<0.1$ ).

The biological data are best represented using a multivariate summary, such as an MDS ordination (Clarke \& Warwick 1994). Fig. 6 shows the spatial ordination of stations based on species abundances for the set of abiotic variables. In these plots, especially in the first one, the ordination of stations with regard to the horizontal axis can be explained on the basis of a hypothetical hydrodynamism gradient, so that the sites most exposed to currents are clustered to the left and those in calm conditions to the right. However, Stn 5 modifies this general pattern and, especially with silting, its extreme values can lead to a misinterpretation of the plots (Gamito \& Raffaelli 1992). The representations of the rest of the abiotic variables do not explain the station groupings in a consistent manner either.

The limitations of the MDS technique are evident, but it can be used previous to more detailed analyses. The BIO-ENV procedure is considered to be a better approach to the problem. Table 3 shows the combinations of environmental variables which give rise to the largest rank correlation $\left(\rho_{\mathrm{s}}\right)$ between biotic and abiotic sample dissimilarities. The combination of variables which best grouped the stations, in a manner consistent with the ascidian composition, involves hydrodynamism together with SOM $\left(\rho_{\mathrm{s}}=0.82\right)$, and the combination of these with suspended solids $\left(\rho_{s}=0.78\right)$. Hydrodynamism is the single factor which reaches the maximum matching coefficient $\left(\rho_{\mathrm{s}}=0.64\right)$, and when further explanatory variables are added $\rho_{\mathrm{s}}$ increases. However, if silting or suspended organic matter are included the coefficient decreases, probably due to their minor effects on community structure (Clarke \& Ainsworth 1993)

If the most important environmental factors for structuring the community were known, the localities having rather similar values for these factors would be expected to present rather similar ascidian composition, and an ordination based on this environmental data would group stations in the same way as for the biotic plot (Clarke \& Warwick 1994). Fig. 7a shows the MDS of species abundance at 10 stations (Stn 5 removed). The remaining plots in this figure are those for the best 2- and 3-variable combinations selected by BIO-ENV and that for the complete set of variables measured. As Clarke \& Ainsworth (1993) stated, for consistency of presentation, these plots are also MDS ordinations, yet based on the Euclidean distance of normalised abiotic variables. This approach would therefore be acceptable, since the small number of variables lead to only minor differences between MDS and the corresponding Principal Components Analysis, which is expected when the higher-dimensional structure is well-represented in 2 dimensions (note the low values of stress obtained).
Fig. 6. Two-dimensional MDS ordination of stations. Superimposed circles represent the annual averages for each of the abiotic variables (stress = 0.05 )
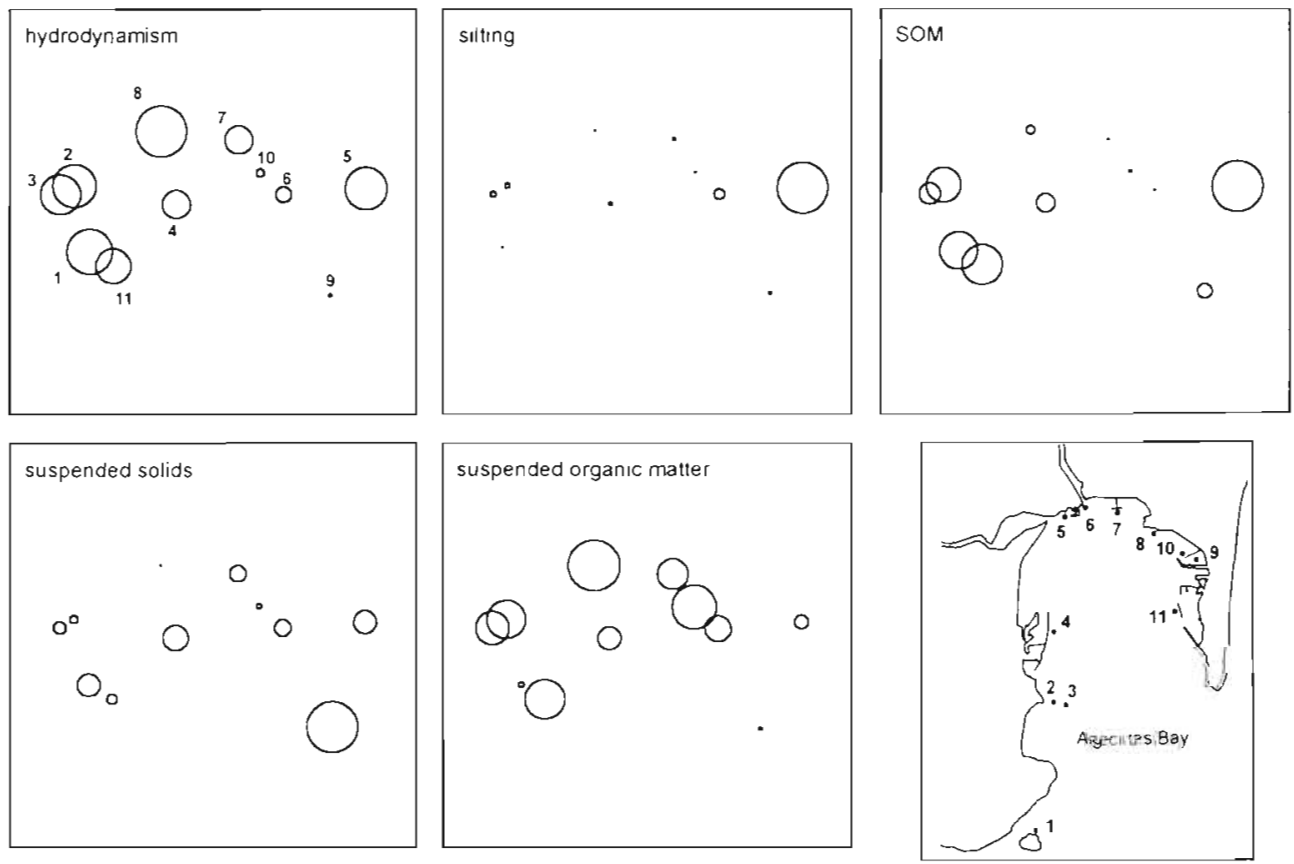
Table 3. Results of BIO-ENV analysis: combinations of environmental variables, taken $k$ at a time, ylelding the 'best matches' of biotic and abı.otic similarity matrixes for each $k$, as measured by standard Spearman coefficient $\rho_{\mathrm{s}}$. Bold type indicates the combination with maximum $\rho_{\mathrm{s}}$ overall. Environmental factors: hyd = hydrodynamism; susOM = suspended organic matter (percentage); SOM = organıc matter in the silt (percentage) $;$ sus = suspended solids; silt = silting

\begin{tabular}{|c|c|c|c|c|c|}
\hline \multirow{2}{*}{$\frac{k}{1}$} & \multicolumn{5}{|c|}{ Best variable combinations $\left(\rho_{s}\right)$} \\
\hline & $\begin{array}{l}\text { hyd } \\
(0.64)\end{array}$ & $\begin{array}{l}\text { SOM } \\
(0.50)\end{array}$ & $\begin{array}{l}\text { sus } \\
(0.21)\end{array}$ & $\begin{array}{c}\text { susOM } \\
(0.17)\end{array}$ & $\begin{array}{c}\text { silt } \\
(-0.07)\end{array}$ \\
\hline 2 & $\begin{array}{l}\text { hyd, SOM } \\
\quad(0.82)\end{array}$ & $\begin{array}{c}\text { SOM, sus } \\
(0.66)\end{array}$ & $\begin{array}{c}\text { SOM, susOM } \\
(0.56)\end{array}$ & $\begin{array}{l}\text { hyd, sus } \\
(0.49)\end{array}$ & \\
\hline 3 & $\begin{array}{c}\text { hyd, sus, SOM } \\
(0.78)\end{array}$ & $\begin{array}{l}\text { hyd, SOM, susOM } \\
(0.74)\end{array}$ & $\begin{array}{c}\text { hyd, SOM, silt } \\
(0.64)\end{array}$ & $\ldots$ & \\
\hline 4 & $\begin{array}{l}\text { hyd, susOM, SOM, sus } \\
\{0.67\}\end{array}$ & $\begin{array}{c}\text { hyd, susOM, SOM, silt } \\
(0.65)\end{array}$ & $\begin{array}{l}\text { hyd, susOM, SOM, silt } \\
\qquad(0.61)\end{array}$ & $\ldots$ & \\
\hline 5 & $\begin{array}{c}\text { hyd, susOM, SOM, sus, silt } \\
(0.62)\end{array}$ & & & & \\
\hline
\end{tabular}

The high degree of concordance between biotic and abiotic plots in Fig. 7 is remarkable, particularly ordinations (a) and (b), which group the sites in a very similar fashion. The cluster formed by Stns 1 to 3 and 11, which are located in the outer zone of the bay, are both consistent in the first 3 plots as is the poor relationship of Stn 9 to the others. Table 3 shows how $\rho_{\mathrm{s}}$ declines slightly when further variables, apart from those most relevant, are added; this is also reflected in the corresponding MDS. In fact, the BIOENV procedure has a natural stopping rule for the cases where $\rho_{\mathrm{s}}$ decreases with inclusion of unimportant variables (Clarke \& Ainsworth 1993). This is shown in the MDS based on complete abiotic data (Fig. 7d), where the lack of concordance with the biotic MDS is obvious.
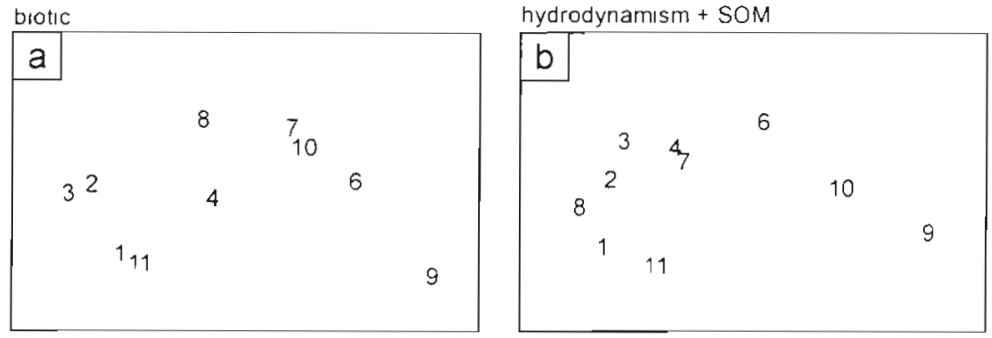

hydrodynamism + SOM + suspended solids

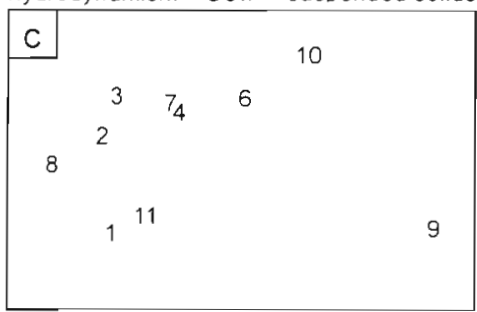

all environmental variables

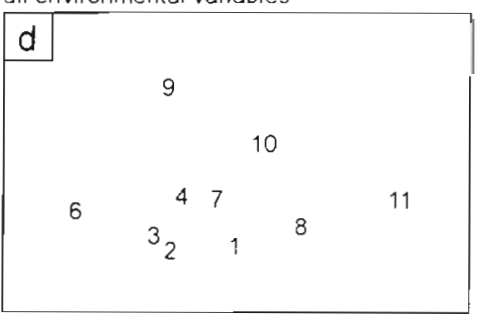

Fig. 7. MDS plots of 10 sampling stations based on: (a) abundance data of 38 ascidian species; (b) and (c) the best 2 - and 3-variable combinations of transformed environmental variables; and (d) all environmental variables (see text). Stress values are: $0.04 ; 0 ; 0.01$; and 0.03 , respectively
On the other hand, the highest $\rho_{\mathrm{s}}$ obtained (close to 1) shows a strong influence of the abiotic variables on the ascidian populations, but it is difficult to see if they are true environmental gradients, since their level of influence on each species remains cryptic. A CCA could be useful for solving this problem, given that in the resulting biplots the species ordination is directly related to the variation of abiotic factors (ter Braak 1986).

In order to avoid distortions which can be caused by rare data (both biotic and abiotic variables), all data from Stn 9 and of Ascidiella aspersa and Molgula bleizei were removed. Furthermore, as suspended solids and the respective organic matter proportions were strongly correlated $(r=-0.92 ; p<0.05)$, the former variable was omitted so that multi-colinearity problems would not occur.

In this manner, CCA was conducted on a revised set of data from 4 environmental variables recorded at 10 stations with a total of 36 species found. The biplot of species and hydrological factors provided by CCA is shown in Fig. 8. Axes I and II explain $73.4 \%$ of total variance in the data, with eigenval. ues of 0.32 and 0.11 , respectively. The abiotic factors most related to axis I are hydrodynamism and SOM, whereas silting is close to axis II (see Table 4). The robustness of the analysis was determined using the Monte-Carlo permutation test (Hope 1968, in ter Braak 1988). The results were as follows: F-ratio $=2.1 ; \mathrm{p}<0.01$. The outcome of CCA was also checked by comparing the species-factor correlations with those obtained by Correspondence Analysis (CA) and Detrended Correspondence analysis (DCA), where no evident differences were found.

In the biplot, species are expressed as points and environmental factors as 


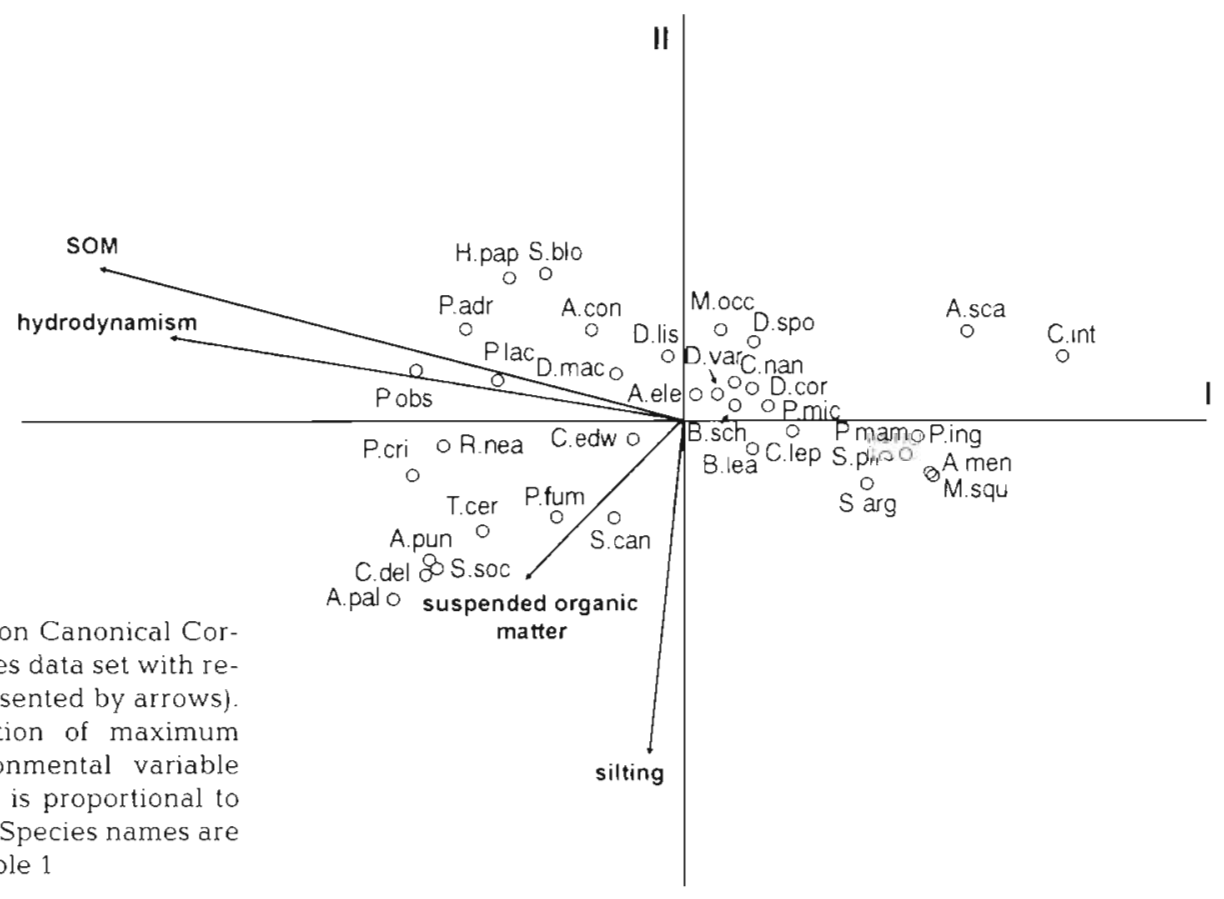

Fig. 8. Species-factor biplot based on Canonical Correspondence Analysis of a 36 species data set with respect to the abiotic variables (represented by arrows) Each arrow points in the direction of maximum change of the respective environmental variable across the diagram, and its length is proportional to the rate of change in this direction. Species names are abbreviated from Table 1

arrows. The length of an arrow indicates the importance of this factor. Each arrow determines a direction or axis in the diagram, obtained by extending the arrow in both directions. The projections of a species on this axis shows its preference for high or low values of this environmental gradient (ter Braak 1986). We thus infer that Pseudodistoma obscurum, Polycitor cristalinus, Polycitor adriaticum, Synoicum blochmanni, Halocynthia papillosa and Rhopalaea neapolitana prefer areas highly exposed to currents and high levels of SOM; species such as Aplidium punctum, Trididemnum cereum, Clavelina dellavallei and Stolonica socialis have the highest weighted average with respect to suspended organic matter; while Ciona intestinalis, Ascidiella scabra, Styela plicata, Synoicum argus, Microcosmus squamiger, Ascidia mentula and Phallusia mammillata are most abundant in calm sites where highest contents of SOM (absolute values) are reached. The remaining species prefer average values or show no clear preferences.

Table 4. Canonical coefficients of and intraset correlations of environmental variables with the first 2 axes of CCA. susOM: suspended organic matter (percentage); SOM: organıc matter in the silt (percentage)

\begin{tabular}{|lrrrr|}
\hline Variables & \multicolumn{3}{c}{$\begin{array}{c}\text { Canonical coefficients } \\
\text { Axis 1 }\end{array}$} & \multicolumn{2}{c|}{ Antraset correlations } \\
& & & Axis 1 & Axis 2 \\
\hline Silting & -0.039 & -0.713 & -0.041 & -0.770 \\
susOM & -0.223 & -0.298 & -0.236 & -0.322 \\
Hydrodynamism & -0.695 & 0.144 & -0.737 & 0.156 \\
SOM & -0.779 & 0.260 & -0.827 & 0.281 \\
& & & & \\
\hline
\end{tabular}

\section{DISCUSSION}

\section{Relation to abiotic variables}

In benthic communities, physical disturbance, predation and competition are considered to be the most important factors affecting the abundance and distribution of species although, in relation to ascidians, the significance of larval behaviour must also be taken into consideration (Buss 1979, Svane \& Lundälv 1982, Davis 1987, Svane \& Young 1989). Along with these factors, the substrate features (nature, size and availability) determine the composition of benthic systems (Jackson 1977b).

In Algeciras Bay, we find that the heterogeneity of the environments investigated was conditioned by the harbour works and urban developments existing along its littoral. This physical variability, along with the different types of urban and industrial wastes, clearly affects the number and composition of species present, which have different levels of adaptation and tolerance. Therefore, the distinct influence that the major environmental factors have along the coastline should be considered before the principal trends in the spatial distribution of ascidians can be established.

The similarity analyses show a clear correspondence between the levels of species grouping and the type and location of substrates in the bay. Those species which prefer light, shallow environments and which colonize artificial surfaces (Microcosmus squamiger, Styela plicata, Phallusia mammillata, Synoicum argus and Clavelina lepadiformis) were more abundant in 
the central zone of the bay. At the other extreme, those species best adapted to exposed environments but sensitive to human influence (transformation of substrates, wastes and harbour activities) were abundant in the outer zone, where extensive natural rock formations are present. These species were mainly Aplidium punctum, Aplidium conicum, Pseudodistoma obscurum, Clavelina dellavallei, Trididemnum cereum and Stolonica socialis.

Previous studies have proven how climatic factors, such as light or temperature, along with hydrological factors, such as salinity, can determine some processes: release of larvae and their settlement (Watanabe \& Lambert 1973, Numakunai \& Hoshino 1980, Davis 1989); reproductive cycles (Svane 1984); or the spatial and seasonal distribution of species (Brunetti \& Menin 1977). Temperature can be a important factor in some areas with large fluctuations, such as the Scandinavian countries or the North Sea, although in temperate zones (mainly the Mediterranean coasts), it is a critical factor which does not seem to affect the local distribution of ascidians (Fiala-Médioni 1972, 1974) so much as their biological cycles (Turon 1988). The values of temperature and salinity recorded in Algeciras Bay during the research period showed some seasonality, but did not show significant differences among sampling stations. However, the other abiotic variables considered (both individually and in joint form) discriminate between the environmental features which affect the stations.

Chimenz et al. (1985) considered environmental energy (from a hydrodynamic point of view) as an important factor with respect to the changes in the vertical and horizontal zonation patterns in marine communities, mainly in ascidian populations. As in other sessile filter-feeders, ascidian populations depend on water movement which guarantees food supply. Nevertheless, high wave conditions can produce harmful effects on many species (Monniot 1965, 1967). On the other hand, silting has a clear influence on fixed animals; ascidians are adversely affected by excessive sediment deposition which causes burial and clogging of the siphons and the branchial wall (Bakus 1968). Also, the additive action of silting and high hydrodynamism has injurious consequences due to the mechanically abrasive effects of the suspended inorganic particles on living organisms (Carballo \& GarcíaGómez (1994).

The influence of any environmental variable will be related both to the exposition rate of animals and to the level of tolerance which they have acquired. In general, the response of benthic species to a worsening of the abiotical conditions (stress increase) does not seem to adjust to a linear model, but shows unimodal or exponential behaviour. The local distribution pat- terns of the ascidians we analyzed showed this trend with respect to hydrodynamism and silting. The values of the former variable did not reach lethal levels, although some species which prefer exposed zones (Aplidium punctum, Clavelina dellavallei, Didemnum maculosum, Phallusia fumigata and Trididemnum cereum) were absent from the most highly exposed areas (e.g. Stn 1, where hydrodynamism reached $17.6 \mathrm{~V}$ ). Other species (Phallusia mammillata, Microcosmus squamiger, Diplosoma spongiforme and Synoicum argus) were found along almost all of the bay's coastline, although their abundance was clearly superior at inner and more protected locations.

On the other hand, extreme sediment deposition normally results in impoverishment of the ecosystem (Bakus 1968). This accounts in part for the low incidence of settled organisms in regions of excessive sedimentation. However, this effect is not a continuous phenomenon since it appears only when certain critical values are reached. This aspect can be interred from Fig. 5a if we consider (assuming the reserves evidenced by Manus \& Pauly 1990) that an index of diversity can be useful in indicating the degree to which a community is stressed. Maximum silting values (close to $200 \mathrm{~g} \mathrm{~m}^{-2} \mathrm{mo}^{-1}$ ) were recorded at Stn 5, which was located near the Palmones River mouth. There we found the poorest ascidian community (this was also true of other benthic groups such as sponges or bryozooans).

The diversity and abundance of benthic filterfeeders seems to be associated with the proportion of organic matter existing in the water column as well. In Algeciras Bay we found that ascidian richness increased when the percentage of organic matter (both in suspension and in the silt) rose. This occurred at the outer stations (Stns 1 to 3 and 11). Nevertheless, the principal supply of organic material comes from industrial and urban wastes (Wait et al. 1990) which are mainly concentrated in the inner zone, where we measured the highest organic contents (in terms of absolute values).

\section{Statistical approach}

Natural communities generally comprise a large number of species, and changes in community structure are determined by a suite of abiotic variables to which each of the species in the community can respond differently. Thus, multivariate methods of classification and ordination have been most efficient, and are now very commonly used in ecological studies

In this paper, besides classical techniques such as clustering and non-metric MDS ordination, we used the BIO-ENV procedure and CCA, which we con- 
sidered to be complementary techniques. They are conceptually different, yet we recommend their joint application for certain studies.

BIO-ENV has, as a principal goal, maximum freedom in the choice of dissimilarity measures which are individually relevant to the biological and environmental contexts (Clarke 1993). This contrasts with the direct gradient methods, such as CCA, in which the speciesenvironment relationships are considered and accounted for at an early stage of the analysis and can produce undesirable effects in the resulting plots. However, the relative simplicity of both the concept and the absence of final graphical results is the greatest strength of BIO-ENV (Clarke \& Ainsworth 1993). CCA leads to very clear interpretations from resulting biplots, where species and abiotic variables can be simultaneously plotted showing the speciespreferences. Their evident differences aside, the more immediate advantage of both methods is their ability to detect and discriminate those irrelevant abiotical variables which do not affect the species distribution. Furthermore, in both cases and for computing simplicity, the values of environmental variables were assumed to be constant at each station. This constraint is difficult to maintain in natural systems where abiotical components are subjected to seasonality and other natural changes.

Therefore, we think that both methods should be considered as 'exploratory tools' BIO-ENV allows us to previously select those more significative environmental factors (avoiding those unimportant to the community), while CCA shows the possible existence of real environmental gradients as well as the level of response of the species to these.

\section{Ascidians as marine bioindicators}

Some species of Ciona, Microcosmus or Pyura have long been studied because of their ability to accumulate certain trace elements from seawater, and are considered as marine pollution indicators in monitoring the release of industrial wastes into the marine environment (Papadopoulou \& Kanias 1977). In fact, the very resistance of several ascidians to many pollutants explains why they make up such an important part of the fouling fauna of ports all over the world.

In Algeciras Bay, the hard substrates in harbour zones, i.e. vertical walls, pilings, the undersides of floating docks and bouys, along with other man-made structures, were almost totally covered by a living layer, which consisted of many solitary ascidians (Microcosmus squamiger) living on top of one another in dense aggregations, which, together with barnacles and mussels, made up a virtual surface over which the rest of the fouling members were settled. These tightly clumped populations of the same species apparently appear in response to high levels of organic matter in the water column, as well as to an intense proliferation of bacteria (Monniot et al. 1991). However, the presence of a single indicator species cannot be utilized as a substitute for all other research or monitoring programs (Soule 1988). Thus, it is important to detect all other companion species, although they may not be considered as indicators at first.

Turbidity and lack of water renewal also favour the survival of ascidian larvae and their successful settlement. This explains the abundance of this group in relation to other benthic organisms. Phallusia mammillata, Synoicum argus, Styela plicata, Clavelina lepadiformis and Diplosoma spongiforme were also frequent species in transformed environments, but these species have also been found in other less-stressed habitats in the bay. Conversely, some species that have never been found in areas under environmental stress could be taken as bioindicators of natural conditions, although obviously only on a local level (Pseudodistoma obscurum, Aplidium punctum, Stolonica socialis, Clavelina dellavallei and Halocynthia papillosa among others).

In this work we have not considered any measurement of polluting agents in the study area, nor any sources or gradients of contamination there established. We have only analyzed the distributional patterns of ascidians with respect to the disposal and spatial heterogeneity of hard substrates, along with the tolerance and adaptation levels that the species show in relation to a suite of environmental factors. On this basis, and given all the considerations just explained, we propose 3 categories for classifying the species' response to environmental stress as shown in Table 5
Table 5. Classification of ascidians species according to their response to environmental stress

\begin{tabular}{|lll|}
\hline Regressive spp. & Transgressive spp. & Tolerant spp. \\
\hline Aplidium conicum & Ciona intestinalis & Aplidium elegans \\
Aplidium punctum & Clavelina lepadiformis & Ascidia mentula \\
Clavelina dellavallel & Diplosoma spongiforme & Ascidiella aspersa \\
Didemnum maculosum & Phallusia mammllata & Botryllus leachi \\
Halocynthia papillosa & Microcosmus squamiger & Botryllus schlosseri \\
Phallusia fumigata & Synoicum argus & Ciona edwardsi \\
Polycitor adriaticum & Styela plicata & Clavelina nana \\
Pseudodistoma obscurum & & Diplosomalisterianum \\
Stolonica socialis & & Distomus variolosus \\
Trididemnum cereum & & Synoicum blochmanni \\
& & \\
\hline
\end{tabular}


(1) Regressive species are those found in natural and non-perturbed environments which disappear or reduce their populations suddenly when stress increases. These sensitive species are generally colonial and solitary forms with long life spans (perennial or pluriannual) and low growth. They are more ecologically specialized, likely to use a confrontational, rather than a fugitive, strategy (Jackson 1979), and also exhibit several adaptations to ensure survival (production of spicules, thick tunic or chemical defenses).

(2) Transgressive species are dominant in harbour areas and nearby zones with highly transformed substrates, low rate of water renewal and excess silting and suspended matter. These species can also be found in conserved areas although they never appear as dominant. They are commonly typical of biofouling and categorized as pioneers and opportunists; they mainly adopt a solitary strategy and have large bodies and wide apertures which prevent clogging by suspended particles. Colonial forms are often sheet-like incrusting ascidians which grow quickly under favourable conditions and form irregularly shaped colonies.

(3) Tolerant species are euritypical species which are capable of living under almost any conditions, even under a certain degree of stress, although their populations decrease in the most perturbed locations. They colonize both natural rocks located in the outer zone of the bay and vertical walls of ports in the middle zone, while they are absent from internal harbour areas with low water movement.

In summary, all the species we studied showed a certain tolerance to diverse environmental factors, which clearly modified their abundance patterns among the localities. Some problems appeared when the abundance of indicator species was used in an absolute sense as a measurement of the intensity of perturbation (Warwick 1993). Interpretations of the community structure on this basis are commonly intuitive and subjective; in our case, the abundance coding produced even less suitable results. Moreover, the absence of indicators cannot be taken to mean the absence of perturbation, but the clear dominance of a well-known bioindicator, in addition to the relative abundance of its common companion species, should be strong proof. Also, whereas other less subjective tools than bioindicators can unequivocally proclaim an abnormal situation, these indicators should probably be better used as evidence to confirm the results of a host of other alteration assessment methods.

Acknowledgements. The authors thank Ms Alma Velasco for translating the manuscript, as well as 3 anonymous reviewers for their valuable suggestions. We also thank the enterprises and institutions that are sponsoring the research project 'Estudio biológico de las comunidades bénticas de la Bahía de
Algeciras': Compañia Española de Petróleos S.A. (CEPSA), Fundación Sevillana de Electricidad, Excmo, Ayuntamiento de los Barrios and Mancomunidad de Municipios del Campo de Gibraltar, whose support has made possible a great part of the fieldwork necessary for this study.

\section{LITERATURE CITED}

Bakus GJ (1968) Sedimentation and benthic invertebrates of Fanning Island, Central Pacific. Mar Geol 6:45-51.

Bakus GJ (1990) Quantitative ecology and marine biology. AA. Balkema, Rotterdam

Bell MV, Pirie BJ, Mcphail DB, Goodman BA, Falk-Petersen IB, Sargent JR (1982) Contents of vanadium and sulphur in the blood cells of Ascidia mentula and Ascidiella aspersa. J Mar Biol Ass UK 62:709-716

ter Braak CJF (1986) Canonical correspondence analysis: a new eigenvector technique for multivariate direct gradient analysis. Ecology 67(5):1167-1179

ter Braak CJF (1988) CANOCO a FORTRAN program for canonical community ordination by (partial) (detrended) (canonical) correspondence analysis, prncipal components analysis and redundancy analysis. TNO Inst Appl Comp Scl Stat Dept, Wageningen

Bray RJ, Curtis JI (1957) An ordination of the upland forest communties of southern Wisconsin. Ecol Monogr 27. $325-349$

Brunetti R, Menin F (1977) Ascidians of the laguna Venetta. II. Distribuition and ecological observatıons. Boll Zool 44: $337-352$

Buss LW (1979) Habitat selection, directional growth and spatial refuges: why colonial animals have more hiding places. In: Larwood G, Rosen BR (eds) Systematics of colonial organisms. Academic Press, London, p 499-555

Camiñas JA. (1987) La Bahía de Algeciras: características oceanográficas y biológicas. Contaminación y áreas de protección. Informe Delegación de Ecología y Medio Ambiente. Ayto Algeciras, Algeciras

Carballo JL, Garcia-Gomez JC (1994) The northeastern Atlantic species Mycale micracanthoxea Buiser, Van Soest, 1977 (Porifera, Poecilosclerida) in the Strant of Gibraltar (southern Spain). Beaufortia 44(2):11-16

Carballo JL, Naranjo SA, García-Gómez JC (1996) The use of sponges as stress indicators in marine ecosystems at Algeciras Bay (southern Iberian Peninsula). Mar Ecol Prog Ser 135:109-122

Carballo JL, Sánchez-Moyano JE, García-Gómez JC (1994) Taxonomical and ecological remarks on boring sponges (Clionidae) from the Straits of Gibraltar (southern Spain): tentative biolndicators? Zool J Linn Soc 112:407-424

Chimenz C, Fresi E, Brunetti R (1985) Richerche sul popolament bentonici di substato duro del porto d'Ischia: Ascidiacei. Cah Biol Mar 26:15-33

Clarke KR (1993) Non-parametric multivariate analyses of changes in community structure. Austr J Ecol 18:117-143

Clarke KR, Ainsworth M (1993) A method of linking multivariate community structure to environmental variables. Mar Ecol Prog Ser 92:205-219

Clarke KR, Green RH (1988) Statistical design and analysıs for a 'bjological effects' study. Mar Ecol Prog Ser 46:213-226

Clarke KR, Warwick RM (1994) Change in marine commun.1ties. An approach to statistical analysis and interpretation. Natural Environment Research Council UK

Conradi M. Cervera, JL (1995) Variability in trophic dominance of amphipods with the bryozoan Bugula neritina (L., 1758) in Algeciras Bay (Southern Iberian Penunsula). 
Pol Arch Hydrobiol 42(2):483-494

Davis AR (1987) Variation in recruitment of the subtidal colonial ascidian Podoclavella cylindrica (Quoy y Gaimard): the rôle of the substratum choice and early survival. J Exp Mar Biol Ecol 106:57-71

Davis AR (1989) Temperature correlates with the daily release of larvae and their settlement in a temperate Australian ascidian. In: Ryland JS, Tyler PA (eds) Genetics and distributions of marine organisms. Olsen \& Olsen, Fredensborg, p 61-65

Fiala-Médioni A (1972) Les peuplements sessiles des fonds rocheux de la région de Banyuls-Sur-Mer: AscidiesBryozoaires. Vie Milieu 23(1B):143-182

Fiala-Medioni A (1974) Ascidies du benthos rocheux de Banyuls-Sur-Mer. Inventaire faunistique et notes écologiques. Vie Milieu 34(1B):193-207

Field JG, Clarke KR, Warwick M (1982) A practical strategy for analysing multispecies distribution patterns. Mar Ecol Prog Ser 8:37-52

Gambi MC, Buia MC, Casola E, Scardi M (1989) Estimate of water movement in Posidonia oceanica beds: a first approach. In: Bouderesque DF, Meinesz A, Fresi E, Gravez $V$ (eds) International Workshop of Posidonia Beds. GIS Posidonie Publ 2:101-112

Gamito S, Raffaelli D (1992) The sensivity of several ordination methods to sample replication in benthic surveys. J Exp Mar Biol Ecol 164:221-232

Gauch HG (1982) Multivariate analysis in community ecology. Cambridge University Press, Melbourne

Jackson JBC (1977a) Competition on marine and hard substrata: the adaptative significance of solitary and colonial strategies. Am Nat 3(980):743-767

Jackson JBC (1977b) Habitat area, colonization, and development of epibenthic communities structure. Proc 11 th Eur Mar Biol Symp, Pergamon Press, Oxford, p 349-358

Jackson JBC (1979) Morphological estrategies of sessile animals. In: Larwood G, Rosen BR (eds) Systematics of colonial organısms. Academic Press, London, p 499-555

Kruskal JB, Wish M (1978) Multidimensional scaling. Sage Publications, Beverly Hills

Magurran AE (1989) La diversidad ecológica y su medición Vedrá, Barcelona

Maldonado M. Uriz M (1995) Biotic affinitjes in a transitional zone between the Atlantic and the Mediterranean: a biogeographical approach based on sponges. J Biogeogr 22 89-110

Manus JW, Pauly D (1990) Measuring ecological stress: variations on a theme by RM Warwick. Mar Biol 106:305-308

Monniot C (1965) Les 'blocs a Microcosmus' des fonds chalutables de la region de Banyuls-Sur-Mer. Vie Milieu $6(2 \mathrm{~B}): 819-849$

Monnot C (1967) Problemes ecologiques poses par l'observation des ascidies dans la zone infrahtorale. Helgol Meeresunters 15(1/4):371-375

Monniot C, Monniot F, Laboute P (1991) Coral reef Ascidians of New Caledonia. L'Orstom, Paris

Monniot F (1978) Connaissances actuelles sur les ions metalliques chez les ascidies. Actual Biochim 185-194

Moore PG (1972) Particulate matter in the sublittoral zone of

This article was submitted to the editor an exposed coast and its ecological significance with special references to the fauna inhabiting kelpholdfasts. J Exp Mar Biol Ecol 10: 9-80

Naranjo SA, García-Gómez JC (1993) The arctic species Het erostigma separ Ärnbäck-Christie-Linde. 1924 (Ascidiacea: Pyuridae) in the Strait of Gibraltar (southern Spain). Beaufortia 43(7):116-123

Numakunai T, Hoshino Z (1980) Periodic spawning of three types of the ascidian Halocynthia roretzi (Drasche), under continuous light conditions. J Exp Zool 212:381-387

Palmer MW (1993) Putting thinks in even order: the advantages of Canonical Correspondence Analysis. Ecology $74(8): 2215-2230$

Papadopuolou C, Hadzistelios I. Grimanis AP (1972) Trace element uptake by Cynthia claudicans (Savigny). Greek Limnol Oceanogr 11:651-663

Papadopuolou C, Kanias G (1977) Tunicate species as marine pollution indicators. Mar Pollut Bull 8(10):229-331

Sneath PHA, Sokal RR (1973) Numerical taxonomy. The principles and practique of numerical classification. WH Freeman \& Co, San Francisco

Soule DF (1988) Marine organisms as indicators: reality or wishful thinking? In: Soule F, Kleppel GS (eds) Marine organisms as indicators II. Springer-Verlag, Berlin

Strickland JDH, Parsons TR (1960) A manual of seawater analysis. Bull Fish Res Bd Can 122:1-172

Svane I (1984) Observations on the long-term population dynamics of the perennial ascidian, Ascida mentula O. F. Müller, on the Swedish west coast. Biol Bull 167:630-646

Svane I, Lundälv T (1982). Persistence stability in ascidian populations: long-term population dynamics and reproductive pattern of Pyura tesselata (Forbes) in Gullmarfjorden on the Swedish west coast. Sarsia 67(4):249-257

Svane I, Young CM (1989) The ecology and behaviour of ascidian larvae. Oceanogr Mar Biol Annu Rev 27:45-90

Turon X (1988) The ascidians of Tossa de Mar (NE Spain). II. Biological cycles of the colonial species. Cah Biol Mar 29: $407-418$

Turon X (1990) Distribution and abundance of ascidians from a locality on the northeast coast of Spain. Mar Ecol 11(4) $291-308$

Wait C. Suárez Castaño M, Muñoz Leyva JA (1990) Balance de materia contaminante a la Baha de Algeciras. Sem Qui Mar, Cadiz 5:229-241

Warwick RM (1993) Environmental impact studies on marine communities; pragmatical considerations. Aust $\mathrm{J}$ Ecol 18 : $63-80$

Warwick RM, Clarke KR (1993) Comparing the severity of disturbance: a meta-analysis of manne macrobenthic community data. Mar Ecol Prog Ser 92:221-231

Watanabe $H$, Lambert $C$ (1973) Larva release in response to light by the compound ascidians Distapla occidentalis and Metandrocarpa taylori. Biol Bull 144(3):506-566

Wright JF, Furse MT, Armitage PD (1994) Use of macroinvertebrate communities to detect environmental stress in running waters. In: Sutcliffe DW (ed) Water quality and stress indicators in marine and freshwater systems: linking levels of organization. Freshwater Blological Association Special Publications UK, p 15-34

Manuscript first received: March 11, 1996

Revised version accepted: July 11, 1996 